Etikonomi

Volume 14 (1), April 2015

P-ISSN: 1412-8969; E-ISSN: 2461-0771

Halaman $1-16$

\title{
UPAYA MENINGKATKAN NIAT PEMBELIAN PRODUK RAMAH LINGKUNGAN MELALUI NILAI, RISIKO, DAN KEPERCAYAAN TERHADAP PRODUK HIJAU
}

\author{
Jati Waskito \\ Fakultas Ekonomi dan Bisnis Universitas Muhammadiyah Surakarta \\ jw271@ums.ac.id
}

\begin{abstract}
.
This study aims to analyze the public perception of value, risk, and trust of green products and developing green marketing model by considering the environmental friendliness of the product, the perception of the value of products, and the risk of products to enhance the consumer's intention to purchase green products. This research used 292 respondents as a sample research. Using a structural equations mode, this research found that the public reward and risk products significantly influence consumers' willingness to buy green products. While the trust is not able to increase green purchasing their desires, and cannot be moderating appreciation green value and green risk to increase green purchasing green
\end{abstract}

Keywords: value; risk; trust; consumer's willingness

\begin{abstract}
Abstrak.
Tujuan dari studi ini adalah untuk mendapatkan diskripsi persepsi masyarakat terhadap nilai, risiko, dan tingkat kepercayaan terhadap produk ramah lingkungan berdasarkan karakteristik mereka. Penelitian ini menggunakan 292 responden sebagai sampel. Berdasarkan analisis persamaan struktural ditemukan bahwa variabel green value dan green risk adalah unsur terpenting dalam meningkatkan keinginan masyarakat untuk membeli produk ramah lingkungan. Tingkat penghargaan yang tinggi pada produk hijau dapat meningkatkan kepercayaan dan secara langsung menguatkan keinginan mereka untuk membeli produk tersebut. Apabila perusahaan dapat menekan persepsi masyarakat terhadap risiko produk akan dapat meningkatkan keinginan mereka untuk membeli produk. Tingkat kepercayaan saja yang terbentuk tanpa disertai dengan peningkatan penghargaan terhadap produk hijau, belum mampu meningkatkan keinginan pembelian mereka
\end{abstract}

Kata Kunci: nilai; risiko; kepercayaan; keinginan konsumen

Diterima: 15 Desember 2014; Direvisi: 2 Februari 2015; Disetujui: 20 Februari 2015 


\section{PENDAHULUAN}

Mulai tumbuhnya kesadaran masyarakat terhadap lingkungan berdampak pada kecenderungan perusahaan untuk lebih perduli terhadap perlindungan lingkungan sebagai tanggung jawab sosial mereka (Dwyer, 2009; Lee, 2009). Merespon peningkatan keperdulian masyarakat terhadap lingkungan ini, banyak perusahaan yang berfikir keras untuk dapat memanfaatkan peluang isu ini demi kepentingan bisnis mereka (Haden et al, 2009). Dalam era yang semakin sadar dengan kelestarian lingkungan, perusahaan mulai lebih memperhatikan pemasaran hijau (green marketing) di beberapa industri, seperti industri informasi dan elektronik (Chen, 2010). Namun demikian, tidak semua perusahaan memiliki cukup kemampuan untuk melakukan strategi pemasaran hijau. Jika perusahaan ingin melaksanakan pemasaran hijau dengan sukses, mereka harus mengintegrasikan konsep pemasaran hijau ke dalam semua aspek kegiatan pemasaran secara rutin (Ottman, 1992).

Untuk menunjang kesuksesan peluncuran produk hijau, pemasaran hijau sangat berperan penting dalam menentukan kesuksesan penjualan produk ramah lingkungan tersebut. Pemasaran hijau tidak hanya menerapkan strategi diferensiasi dengan menciptakan kebutuhan pelestarian lingkungan, tetapi juga faktor lain yang dapat meningkatkan niat pembelian konsumen.

Masyarakat bersedia untuk membeli produk hijau apabila produk tersebut disertai dengan informasi yang memadai dan dapat dipercaya. Hal ini berarti perusahaan harus menyediakan informasi yang dapat dipercaya bagi konsumen mereka dalam rangka untuk mengurangi persepsi negative pelanggan mereka terhadap risiko pemanfaatan produk tersebut (Peattie, 1992). Akan menjadi sulit bagi pemasar untuk meyakinkan pelanggan mereka membeli produk tanpa memberikan informasi yang meyakinkan pada pelanggan mereka. Perusahaan perlu memberikan informasi yang komplit tentang kinerja lingkungan produk untuk mendapatkan kepercayaan dari konsumen mereka. 
Upaya Meningkatkan Niat Pembelian Produk Ramah Lingkungan....

Jati Waskito

Harapan pada produk hijau sering diciderai oleh persepsi bahwa produk tersebut berkualitas rendah atau tidak benar-benar merealisasikan seperti janji-janji yang disebut dalam promosi bahwa produk mereka ramah lingkungan. Pemasar harus menyadari bahwa konsumen tidak hanya terfokus pada isu produk ramah lingkungan saja, tetapi mereka juga harus ingat bahwa konsumen tidak mungkin untuk berkompromi pada atribut produk tradisional, seperti nilai, kualitas, harga, dan kinerja. Produk hijau harus tidak kalah dengan atribut-atribut produk non-green tersebut untuk menarik konsumen.

Kehijauan (keramahan lingkungan) sebuah produk tidak dapat menjamin peningkatan penjualan, bahkan di era hijau sekalipun. Chen dan Chang (2012) berpendapat bahwa perusahaan perlu mengembangkan produk yang memiliki atribut selain keramahan lingkungan tetapi juga atribut produk yang bernilai tinggi untuk meningkatkan niat pembelian konsumen. Selain itu, salah satu elemen kunci strategi pemasaran hijau adalah kredibilitas. Menurunkan persepsi risiko pelanggan dalam mengkonsumsi produk hijau dapat membantu untuk menurunkan skeptisisme pelanggan dan meningkatkan kepercayaan mereka.

Hasil penelitian Waskito dan Harsono (2011) menemukan bahwa konsumen mempunyai tingkat kesadaran yang tumbuh pada produk ramah lingkungan. Namun demikian hasil penelitian tersebut menunjukkan bahwa tumbuhnya tingkat kesadaran tersebut belum disertai dengan tindakan atau keputusan pembelian produk hijau. Akan menjadi suatu penelitian yang menarik apabila dengan menggunakan responden yang sama yakni warga kota Joglosemar dengan menggunakan konsep yang dikemukakan Chen dan Chang (2012), bahwa persepsi nilai produk, risiko produk, dan tingkat kepercayaan terhadap produk mungkin menjadi faktor mengapa mereka belum meningkatkan sikap mereka dari memperhatikan menjadi keinginan untuk membeli. 


\section{METODE}

Definisi dan pengukuran konstruksi dalam penelitian ini adalah sebagai berikut: pertama, persepsi Nilai Hijau. Penelitian ini mengusulkan gagasan "green perceived value" dan mengacu pada Patterson dan Spreng (1997) "penilaian keseluruhan seorang konsumen dari manfaat suatu produk atau jasa antara apa yang diterima dan apa yang diberikan berdasarkan keinginan lingkungan konsumen, harapan berkelanjutan, dan kebutuhan hijau“ pengukurannya meliputi lima item, misalnya berkaitan dengan fungsi perlindungan, kinerja, dan manfaat produk pada lingkungan.

Kedua, persepsi Risiko Hijau. Penelitian ini menggunakan gagasan "green perceived risk" dan mengacu kepada Chen dan Chang (2012) yang mendefinisikan sebagai "harapan negatif konsekuensi lingkungan yang terkait dengan perilaku pembelian", pengukurannya meliputi lima item, misalnya ada sesuatu yang salah dengan performa lingkungan, pemakaian produk tidak sesuai seperti yang diharapkan, kemungkinan bahwa menggunakan produk akan berdampak negatif terhadap lingkungan. Ketiga, kepercayaan Hijau. Mengacu Chen (2010), penelitian ini mendefinisikan kepercayaan hijau sebagai "kesediaan untuk bergantung pada produk, layanan, atau merek berdasarkan pada keyakinan atau harapan karena kredibilitas, manfaat, dan kemampuan kinerja lingkungannya". Pengukurannya meliputi empat item, misalnya: kinerja lingkungan produk dapat diandalkan, klaim promosi dapat percaya , realisasi komitmen untuk lingkungan.

Penelitian ini menggunakan gagasan baru, "green product intention", dan mengacu pada Netemeyer et al. (2005) yang mendefinisikannya sebagai "kemungkinan bahwa konsumen akan membeli produk tertentu karena keinginannya untuk melestarikan lingkungan". Untuk mengukur niat pembelian hijau. Pengukuran variable ini mencakup tiga item. Penelitian ini menggunakan model persamaan struktural (SEM) untuk memverifikasi model penelitian dan hipotesis dengan menggunakan AMOS untuk mendapatkan hasil empiris. SEM dalam penelitian ini meneliti analisis dua tingkat: pengukuran model dan struktur model 


\section{Gambar 1. Model SEM}

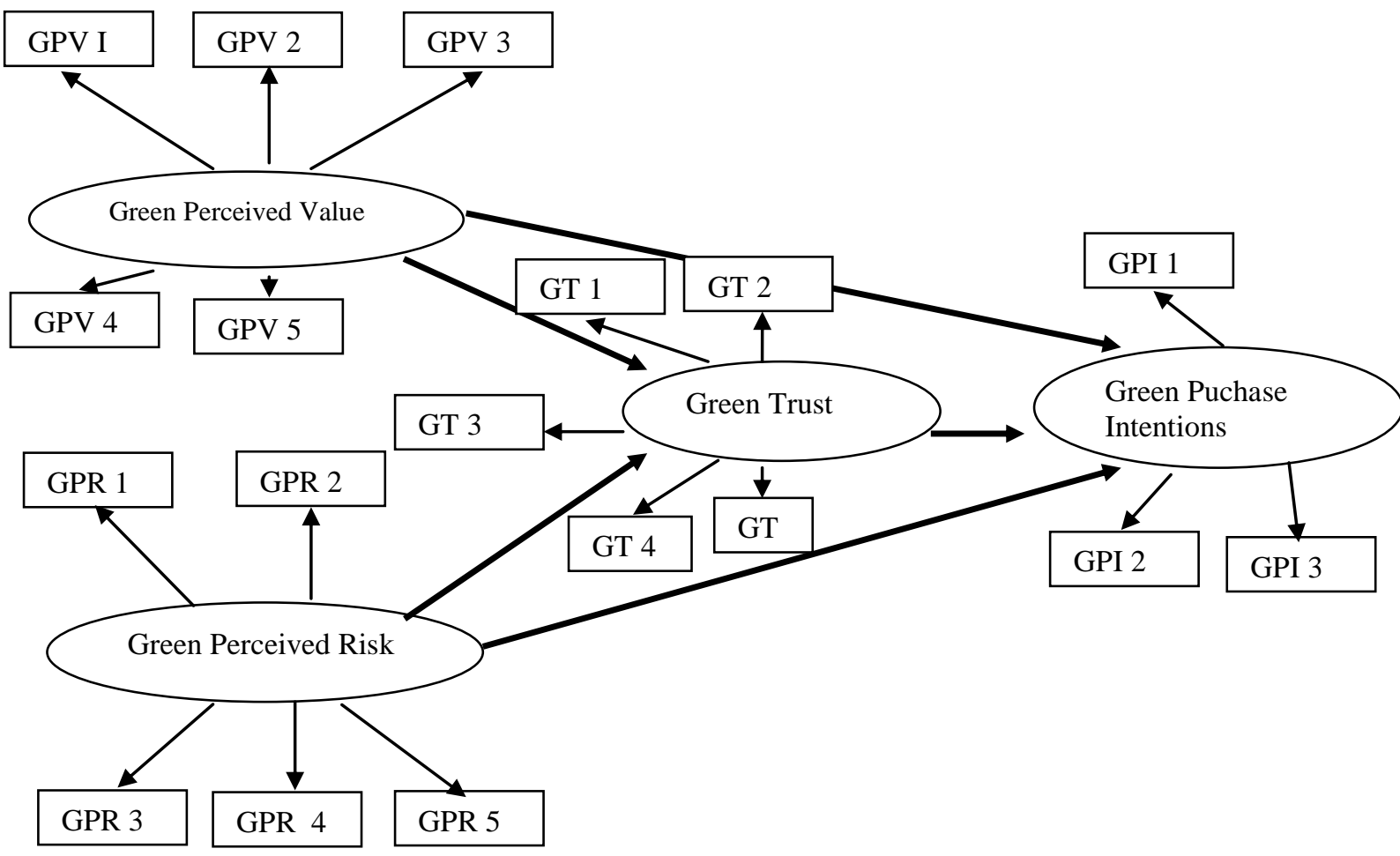

\section{PEMBAHASAN}

Hasil survei di lapangan melalui penyebaran kuesioner sejumlah 300 buah di tiga kota (Jogyakarta, Solo, dan Semarang). Hasil survei lapangan berhasil mendapatkan 296 orang responden yang bersedia berpartisipasi. Hasil ini yang dapat diolah kuesionernya sebanyak 292 responden (97\%), sedangkan sisanya 4 kuesioner (3\%) tidak dipakai karena banyak butir pertanyaan yang tidak dijawab (kosong). Jumlah responden 46.2\% pria dan 53.8\% wanita, yang berusia 31 sd. 40 tahun (40.1\%). Domisili responden di tiga kota sebagai sampel penelitian, yang menunjukkan prosentase yang cukup berimbang. Sebagian besar responden (40.1\%) pernah merasakan makanan organik. Makanan pokok sehari-hari seperti beras dan sayur mayur organik semakin banyak tersedia di toko dan semakin banyak di konsumsi oleh masyarakat. Sementara itu tingkat pendidikan responden didominasi oleh tingkat SMU dan perguruan tinggi (lebih dari 90\%). 
Tabel 1. Hasil Analisis Faktor

\begin{tabular}{lcccc}
\hline & \multicolumn{4}{c}{ Component } \\
& 1 & 2 & 3 & 4 \\
\hline NilaiHij5 &, 807 &,- 078 &, 240 &, 053 \\
NilaiHij4 &, 795 &,- 146 &, 122 &, 348 \\
NilaiHij3 &, 770 &,- 120 &, 207 &, 293 \\
NilaiHij2 &, 760 &,- 184 &, 350 &, 012 \\
NilaiHij1 &, 708 &,- 345 &, 179 &, 211 \\
RisikoHij1 &,- 109 &, 827 &,- 149 &, 040 \\
RisikoHij3 &,- 082 &, 812 &,- 111 &,- 202 \\
RisikoHij4 &,- 151 &, 805 &,- 229 &,- 034 \\
RisikoHij5 &,- 113 &, 755 &,- 030 &,- 197 \\
RisikoHij2 &,- 195 &, 655 &,- 098 &,- 107 \\
PercayaHij4 &, 061 &,- 207 &, 813 &, 080 \\
PercayaHij2 &, 264 &,- 062 &, 804 &, 170 \\
PercayaHij5 &, 179 &,- 180 &, 753 &, 162 \\
PercayaHij1 &, 276 &,- 043 &, 745 &, 149 \\
PercayaHij3 &, 304 &,- 200 &, 667 &, 273 \\
NiatBeli1 &, 196 &,- 074 &, 196 &, 865 \\
NiatBeli2 &, 184 &,- 144 &, 190 &, 865 \\
NiatBeli3 &, 213 &,- 216 &, 230 &, 795 \\
\hline
\end{tabular}

Sumber: Data diolah

Tabel 1 menunjukkan hasil analisis faktor dengan metode principal component analysis mengesktraksi variable manifest mejadi empat faktor berdasarkan eugin value. Tingkat persentasi kumulatif kontribusi seluruh faktor variabel penelitian sebesar $71.240 \%$. Pemberian nama masing-masing faktor sebelumnya sudah ditentukan terlebih dahulu mengingat tujuan analisis faktor untuk penelitian ini adalah untuk meyakinkan apakah butir-butir pertanyaan yang diajukan benar-benar mewakili konstruk variabel yang diinginkan. Hasil pengujian reliabilitas dapat dilihat pada Tabel 2. Berdasarkan Tabel 1 dan 2 dapat dijelaskan bahwa semua butir pertanyaan yang diajukan adalah valid dan reliable. 
Tabel 2. Hasil Uji Reliabilitas Pengukuran Variabel Penelitian

\begin{tabular}{lc}
\hline \multicolumn{1}{c}{ Variabel yang diukur } & Koefisien alpha cronbach \\
\hline Green value & 0.895 \\
Risk value & 0.860 \\
Green trust & 0.876 \\
Purchase intention & 0.890 \\
\hline
\end{tabular}

Sumber: Data diolah

Terdapat beberapa hal yang dapat dijelaskan terkait dengan hasil yang didapat dalam penelitian ini, yaitu: pertama, penghargaan masyarakat terhadap produk ramah lingkungan berkontribusi positif dan signifikan untuk membangun tingkat kepercayaan mereka terhadap kinerja produk tersebut $(\mathrm{R}=$ 0.63; $\mathrm{p}=0.000)$. Kedua, persepsi risiko hijau (kemungkinan buruk) mengkonsumsi produk ramah lingkungan ternyata tidak dapat mematahkan penghargaan mereka pada produk tersebut atau tidak signifikan $(R=0.03 ; p=$ 0.557). Ketiga, kontribusi penghargaan masyarakat terhadap produk ramah lingkungan berkontribusi positif dan signifikan untuk meningkatkan keinginan mereka membeli produk tersebut $(\mathrm{R}=0.22 ; \mathrm{p}=0.022)$. Keempat, kontribusi kepercayaan masyarakat terhadap produk hijau belum mampu meningkatkan keinginan mereka untuk membelinya $(\mathrm{R}=0.116 ; \mathrm{p}=0.179)$. Kelima, persepsi masyarakat terhadap risiko kinerja produk ramah lingkungan berpengaruh secara negatif dan signifikan terhadap keinginan mereka untuk membelinya ( $R$ $=-0.652 ; \mathrm{p}=0.000)$.

Model fit yang baik dalam studi ini menunjukkan bahwa keinginan masyarakat untuk membeli produk ramah lingkungan sangat dipengaruhi oleh beberapa variabel yang diusulkan dalam penelitian ini. Tabel 4 dapat menjawab beberapa hipotesis yang diajukan dalam penelitian ini, sebagai berikut:

H1. "Persepsi nilai hijau (green perceived value) berpengaruh positif terhadap kepercayaan hijau (green trust)" terbukti signifikan $(\mathrm{R}=0.63 ; \mathrm{p}=$ 0.000). hasil ini konsisten dengan penelitian yang dilakukan oleh Patterson dan Spreng (1997), Sweeney et al. (1999), Geyskens (2006), Kim et al. (2008) dan 
Zhuang et al, (2010). Masyarakat memandang bahwa fungsi perlindungan, kinerja, dan manfaat produk hijau dalam menjaga kelestarian lingkungan, serta penghargaan mereka sendiri terhadap lingkungan, dapat meningkatkan rasa kepercayaan mereka terhadap produk tersebut. Masyarakat menjadi semakin percaya dengan kinerja produk, klaim perlindungan produk terhadap kelestarian lingkungan dan janji-janji dalam promosi akan terealiasasikan sesuai kenyataannya.

Persepsi nilai didefinisikan sebagai evaluasi keseluruhan konsumen dari manfaat pada produk atau jasa berdasarkan penilaian seorang konsumen (Patterson dan Spreng, 1997). Penelitian sebelumnya banyak yang meneliti "persepsi nilai" karena memiliki efek positif pada kinerja pemasaran (Sweeney et al., 1999). Persepsi nilai tidak bisa hanya menjadi penentu penting dalam menjaga hubungan pelanggan dalam jangka panjang, tetapi juga memainkan peran penting dalam mempengaruhi niat pembelian (Zhuang et al, 2010). Selain itu, nilai juga dirasakan penting dalam mempengaruhi kepercayaan pelanggan (Kim et al., 2008). Penelitian sebelumnya menyatakan bahwa terdapat hubungan positif persepsi nilai dan kepercayaan pelanggan. Semakin meningkat persepsi nilai konsumen terhadap sebuah produk pasca-pembelian maka akan semakin meningkatkan kepercayaan mereka terhadap produk (Eid, 2011; Sirdeshmukh et al, 2002.). Beberapa perusahaan melebih-lebihkan nilai lingkungan dari produk mereka sedemikian rupa sehingga pelanggan kurang percaya kepada produk mereka lagi (Kalafatis dan Pollard, 1999).

H2." Persepsi risiko hijau berpengaruh secara negatif terhadap kepercayaan hijau" tidak signifikan ( $R=0.03 ; \quad \mathrm{p}=0.557)$. Hasil ini berbeda dengan penelitian yang dilakukan oleh Koehn (2003), Gregg dan Walczak (2008), Eid (2011), dan Chen \& Chang (2012). Hal ini berarti bahwa meskipun kemungkinan-kemungkinan negatif dari pemakaian produk hijau itu akan mereka alami, hal ini tidak memudarkan tingkat kepercayaan mereka. Teori persepsi risiko menyatakan bahwa konsumen tertarik untuk meminimalkan risiko yang mereka rasakan dan bukan untuk memaksimalkan utilitas mereka (Mitchell, 1999). Asimetri informasi membuatnya lebih sulit bagi pembeli 
Upaya Meningkatkan Niat Pembelian Produk Ramah Lingkungan....

Jati Waskito

untuk mengidentifikasi nilai produk yang sebenarnya sebelum melakukan pembelian (Chen dan Chang 2012). Kondisi ini memberikan insentif bagi penjual untuk bertindak jujur. Akhirnya, para pembeli tidak mau membeli produk karena ketidakpercayaan mereka dari penjual yang disebabkan oleh asimetri informasi antara pembeli dan penjual (Gregg dan Walczak, 2008). Jika konsumen merasa risiko tinggi terhadap produk, mereka akan enggan untuk mempercayai produk (Mitchell, 1999). Dengan demikian, penelitian sebelumnya menyatakan bahwa risiko dianggap negatif mempengaruhi persepsi kepercayaan konsumen terhadap sebuah produk (Eid, 2011).

Terdapat hubungan yang kuat antara persepsi risiko dan emosi negatif konsumsi yang memiliki efek langsung pada kepercayaan (Chaudhuri, 1997). Sehingga, risiko yang terkait emosi seperti kecemasan atau kekhawatiran negatif akan mempengaruhi kepercayaan (Chen dan Chang, 2012). Oleh karena itu, penelitian sebelumnya menyatakan bahwa persepsi risiko berpengaruh negatif terhadap kepercayaan pelanggan (Koehn, 2003; Eid, 2011). Dengan semakin meningkatnya tren lingkungan, pelanggan memiliki pertimbangan yang lebih pada lingkungan yang akan meningkatkan persepsi risiko mereka. Oleh karena itu, Chang dan Chen (2012) mengusulkan konsep yang baru dengan apa yang mereka sebut sebagai , "persepsi risiko hijau (green perceived risk)", yang didifinisikan sebagai "harapan negatif konsekuensi lingkungan yang terkait dengan perilaku pembelian".

H3." Kepercayaan hijau berpengaruh secara positif terhadap niat pembelian hijau" terbukti tidak signifikan ( $R=0.116 ; p=0.179)$. Hasil ini berbeda dengan penelitian yang dilakukan oleh Schlosser et al. (2006), Chen (2010) dan Lu et al. (2010). Semakin tinggi tingkat kepercayaan masyarakat terhadap kinerja produk, klaim perlindungan produk terhadap kelestarian lingkungan dan realisasi dari janji-janji produsen dalam promosi, ternyata belum mampu secara signifikan meningkatkan keinginan mereka untuk membelinya. Hal ini berarti masyarakat sudah menunjukkan rasa kepercayaan terhadap produk hijau, tetapi mereka belum memberikan penghargaan terhadap kelestarian lingkungan sebagaimana mestinya. 
Kepercayaan disebabkan dari tiga keyakinan - integritas, manfaat, dan kemampuan - yaitu sebuah harapan salah satu pihak bahwa kata, janji, atau pernyataan dari pihak lain dapat diandalkan (Schurr dan Ozanne, 1985). Selain itu, kepercayaan adalah sejauh mana keyakinan bahwa pihak lain akan berperilaku seperti yang diharapkan (Hart dan Saunders, 1997). Kepercayaan pelanggan adalah penentu fundamental jangka panjang perilaku konsumen (Lee et al, 2011). Oleh karena itu, niat pembelian konsumen dipengaruhi oleh kepercayaan konsumen (Harris dan Goode, 2010). Literatur sebelumnya mengemukakan bahwa kepercayaan pelanggan merupakan penentu niat pembelian konsumen (Schlosser et al., 2006). Jika pembeli memiliki pengalaman kepercayaan dengan penjual, mereka akan memiliki niat pembelian yang semakin meningkat. Dengan demikian, kepercayaan konsumen merupakan anteseden niat pembelian konsumen (van der Heijden et al, 2003).

Penelitian sebelumnya menunjukkan bahwa kepercayaan konsumen akan berpengaruh positif terhadap niat pembelian konsumen (Schlosser et al., 2006). Beberapa perusahaan seringkali terlalu membesar-besarkan kinerja lingkungan dari produk mereka, sehingga pelanggan enggan untuk mempercayai mereka lagi. Dengan demikian, Chen (2010) berpendapat bahwa kepercayaan hijau akan mempengaruhi perilaku pembelian konsumen dalam era lingkungan.

Tabel 3. Evaluasi Model Hipotesis dengan Goodness of Fit Measures

\begin{tabular}{lcc}
\hline \multicolumn{1}{c}{$\begin{array}{c}\text { GOODNESS OF FIT } \\
\text { MEASURES }\end{array}$} & $\begin{array}{c}\text { CALCULATIONS OF } \\
\text { MEASURES }\end{array}$ & ACCEPTABILITY \\
\hline Chi-Square Test & 229,070 & moderate \\
Goodness of Fit Indeks & 0.909 & Accepted \\
Normed Fit Indeks & 0.939 & Accepted \\
Comparative Fit Indeks & 0.964 & Accepted \\
RMSEA & 0.068 & Accepted \\
\hline
\end{tabular}

Sumber: data diolah 
H4. 'Persepsi nilai hijau berpengaruh secara positif terhadap niat pembelian produk hijau" terbukti signifikan $(\mathrm{R}=0.22 ; \mathrm{p}=0.022)$. Hasil ini mendukung temuan dari para peneliti sebelumnya, Zeithaml (1988), Kalafatis dan Pollard (1999) Sweeney dan Soutar (2001), Kardes et al. (2004), Gounaris et al (2007), Chang dan Chen (2008), dan Ashton et a. (2010). Berbeda dengan variabel kepercayaan yang tidak mampu mengangkat keinginan pembelian produk hijau, penghargaan masyarakat terhadap produk hijau ternyata mampu meningkatkan keinginan mereka untuk membelinya. Bahwa fungsi perlindungan, kinerja, dan manfaat produk hijau dalam menjaga kelestarian lingkungan, serta penghargaan mereka sendiri terhadap lingkungan akan meningkatkan rasa senang mereka untuk membeli produk tersebut karena mereka juga akan merasa ikut andil dalam melestarikan lingkungan dengan membelinya.

Penilaian konsumen sering didasarkan pada informasi yang tidak lengkap, persepsi nilai produk yang dianggap sebagai sinyal positif yang akan berpengaruh terhadap niat pembelian (Kardes et al., 2004). Persepsi nilai adalah seperangkat atribut yang terkait dengan persepsi nilai suatu produk, sehingga dapat membangun sebuah dampak positif dan meningkatkan pembelian niat (Ashton et al, 2010). Semenjak adanya beberapa perusahaan yang mempromosikan produk mereka dengan klaim yang menyesatkan tentang nilai lingkungan dari produk mereka, pelanggan enggan untuk membeli mereka produk (Kalafatis dan Pollard, 1999). Oleh karena itu, persepsi nilai hijau memainkan peran lebih penting dalam era lingkungan saat ini. Persepsi nilai adalah salah satu yang paling faktor yang berpengaruh secara signifikan terhadap niat pembelian (Zeithaml, 1988). Penelitian sebelumnya menunjukkan bahwa persepsi nilai berpengaruh secara positif terhadap niat pembelian konsumen (Gounaris et al., 2007). Persepsi nilai yang rendah dapat mengakibatkan hilangnya niat pembelian (Sweeney dan Soutar, 2001). Jika konsumen merasa bahwa nilai suatu produk lebih tinggi, mereka lebih cenderung untuk membeli produk (Chang dan Chen, 2008). 
H5. "Persepsi risiko produk hijau berpengaruh secara negatif terhadap niat pembelian produk hijau", terbukti signifikan $(\mathrm{R}=-0.652 ; \mathrm{p}=0.000)$. Hasil ini konsisten dengan hasil temuan Wood dan Scheer (1996), Mitchel (1999), Harridge dan March (2006), Chang dan Chen (2008), dan Gregg \& Walczak (2008). Semakin tinggi keyakinan bahwa produk hijau kurang ramah terhadap lingkungan, belum memenuhi kriteria ramah lingkungan, dapat mencemari lingkungan, dan reputasi negatif yang lain akan berakibat menurunnya keinginan untuk membeli produk tersebut.

Risiko dianggap memiliki pengaruh negatif terhadap keputusan pembelian pelanggan (Harridge dan March, 2006). Selain itu, persepsi risiko adalah harapan kerugian yang bersifat subyektif, sehingga secara signifikan akan mempengaruhi perilaku konsumen (Mitchell, 1999). Teori persepsi risiko mengungkapkan bahwa pembeli cenderung untuk meminimalkan persepsi risiko mereka daripada untuk memaksimalkan harapan mereka terhdap nilai produk (Mitchell, 1999). Persepsi risiko berpengaruh negatif terhadap niat pembelian (Chang dan Chen, 2008). Informasi asimetri membuat konsumen konsumen cukup sulit untuk menilai nilai produk yang sebenarnya sebelum mereka membeli (Mishra et al., 1998). Situasi ini memungkinkan penjual untuk bertindak oportunis (Mishra et al., 1998). Akhirnya, pelanggan enggan untuk membeli karena informasi asimetri penjual melekat dalam produk ketika melakukan transaksi (Gregg dan Walczak, 2008). Dengan demikian, literatur sebelumnya menunjukkan bahwa pengurangan persepsi risiko dapat meningkatkan niat pembelian pelanggan (Wood dan Scheer, 1996).

Tabel 4. Hasil Estimasi Maximum Likelihood

\begin{tabular}{lllll}
\hline \multicolumn{1}{c}{ Regression Weights } & Estimate & S.E & C.R & Keterangan \\
\hline GreenValue $\rightarrow$ Green Trust & 0.632 & 0.081 & 7,826 & Signifikan \\
Green Risk $\rightarrow$ Green Trust & 0.029 & 0.050 & 0.587 & Tidak signifikan \\
Green Value $\rightarrow$ Purchase Intention & 0.222 & 0.097 & 2.287 & Signifikan \\
Green Trust $\rightarrow$ Purchase Intention & 0.116 & 0.087 & 1.345 & Tidak signifikan \\
Green Risk $\rightarrow$ Purchase Intention & -0.652 & 0.061 & -10.735 & Signifikan \\
\hline
\end{tabular}

Sumber: data diolah 
Upaya Meningkatkan Niat Pembelian Produk Ramah Lingkungan....

Jati Waskito

\section{SIMPULAN}

Model penelitian yang diusulkan dalam penelitian ini dapat mewakili gambaran secara komprehensif faktor-faktor yang dapat mempengaruhi keniatan konsumen untuk membeli produk ramah lingkungan. Variabel green value dan green risk adalah unsur terpenting dalam meningkatkan keinginan masyarakat untuk membeli produk ramah lingkungan. Dengan meningkatkan penghargaan masyarakat terhadap produk hijau akan dapat meningkatkan kepercayaan mereka pada kinerja produk. Tingkat penghargaan yang tinggi pada produk hijau dapat meningkatkan kepercayaan dan secara langsung menguatkan keinginan mereka untuk membeli produk tersebut. Apabila perusahaan dapat menekan persepsi masyarakat terhadap risiko produk akan dapat meningkatkan keinginan mereka untuk membeli produk. Tingkat kepercayaan saja yang terbentuk tanpa disertai dengan peningkatan penghargaan terhadap produk hijau, belum mampu meningkatkan keinginan pembelian mereka.

Terdapat beberapa implikasi manajerial terkait penelitian ini, yaitu: pertama, apabila perusahaan ingin meningkatkan penjualan produk yang mereka klaim sebagai produk ramah lingkungan, maka sebaiknya mereka mengkombinasikan konsep dari persepsi nilai hijau, persepesi risiko hijau, dan kepercayaan hijau pada strategi hijau mereka kepada tahapan perencanaan strategi. Kedua, bahwa pengalaman para peritel adalah merupakan pemberi informaswi yang efektif antara konsumen dan produsen untuk meningkatkan kepercayaan dan penghargaan konsumen terhadap produk hijau, dan mengurangi persepsi mereka terhadap risiko yang mungkin dapat ditimbulkan apabila mengkonsumsi produk hijau. Ketiga, peran penting peritel dalam proses penguatan kepercayaan, penghargaan, dan pengurangan risiko terhadap produk hijau menunjukkan urgensinya bagi perusahaan untuk mengadakan pelatihan pengetahuan produk dan pelayanan prima. Keempat, perusahaan dapat melakukan green marketing yang praktis guna mengurangi persespsi risiko hijau masyarakat. Misalnya dengan adanya garansi uang kembali apabila mereka tidak puas dengan kinerja produk hijau mereka. 


\section{PUSTAKA ACUAN}

Ashton, A.S., et.al. 2010. Hotel restaurant dining: the relationship between perceived value and intention to purchase. Tourism and Hospitality Research, Vol. 10 No. 3, pp. 206-18.

Chang, H.H. \& S.W.Chen. 2012. The impact of online store environment cues on purchaseintention: trust and perceived risk as a mediator. Online Information Review, Vol. 32 No. 6,pp. 818-41.

Chen, Y.-S. 2008. The driver of green innovation and green image - green core competence. Journal of Business Ethics, Vol. 81 No. 3, pp. 531-43.

Chen, Y.-S. 2010. The drivers of green brand equity: green brand image, green satisfaction, and green trust. Journal of Business Ethics, Vol. 93 No. 2, pp. 307-19.

Chen, Y-S. \& H.H. Chang. 2012. Enhance green purchase intentions The roles of green perceived value, green perceived risk, and green trust. Management Decision, Vol. 50 No. 3, 2012 pp. 502-520

Corritore, C.L., et.al. 2003. On-line trust: concepts, evolving themes, a model. International Journal of Human-Computer Studies, Vol. 58 No. 6, pp. 73758.

Dwyer, R.J. 2009. Keen to be green organizations: a focused rules approach to accountability. Management Decision, Vol. 47 No. 7, pp. 1200-16.

Eggert, A. \& W. Ulaga. 2002. Customer perceived value: a substitute for satisfaction inbusiness markets. Journal of Business \& Industrial Marketing, Vol. 17 Nos 2/3, pp. 107-18.

Eid, M.I. 2011. Determinants of e-commerce customer satisfaction, trust, and loyalty in SaudiArabia. Journal of Electronic Commerce Research, Vol. 12 No. 1, pp. 78-93.

Ginsberg, J.M. \& P.N. Bloom. 2004. Choosing the right green marketing strategy. MIT Sloan Management Review, Vol. 46 No. 1, pp. 79-84.

Gounaris, S.P., et.al. 2007. The relationships of customer-perceived value, satisfaction, loyalty and behavioral intentions. Journal of Relationship Marketing, Vol. 6 No. 1, pp. 63-87. 
Upaya Meningkatkan Niat Pembelian Produk Ramah Lingkungan....

Gregg, D.G. \& S. Walczak. 2008. Dressing your online auction business for success: an experiment comparing two e-Bay businesses. MIS Quarterly, Vol. 32 No. 3, pp. 653-70.

Haden, S.S.P., et.al. 2009. Historical, practical, and theoretical perspectives on green management: an exploratory analysis. Management Decision, Vol. 47 No. 7, pp. 1041-55.

Hall, M.K. 2007. Can the building of trust overcome consumer perceived risk online? Marketing Intelligence \& Planning, Vol. 24 No. 7, pp. 746-61.

Harris, L.C. \& M.M.H. Goode. 2010. Online servicescapes, trust, and purchase intentions. Journal of Services Marketing, Vol. 24 No. 3, pp. 230-43.

Hart, P. \& C. Saunders. 1997. Power and trust: critical factors in the adoption and use ofelectronic data interchange. Organizational Science, Vol. 8 No. 1, pp. $23-42$.

Jain, S.K. \& G. Kaur. 2004. Green marketing: an Indian perspective. Decision, Vol. 31 No.2,pp. 168-209.

Kalafatis, S.P. \& M. Pollard. 1999. Green marketing and Ajzen's theory of planned behaviour: a cross-market examination. Journal of Consumer Marketing, Vol. 16 No. 4, pp. 441-60.

Kardes, F.R., et.al. (2004). Consumer inference: a review of processes, bases, and judgment contexts. Journal of Consumer Psychology, Vol. 14 No. 3, pp. 230-56.

Kim, C., et.al. 2008. An empirical study on the integrated framework of e-CRM in online shopping: evaluating the relationships among perceived value, satisfaction, and trust based on customers' perspectives. Journal of Electronic Commerce in Organizations, Vol. 6 No. 3, pp. 1-19.

Koehn, D. 2003. The nature of and conditions for online trust. Journal of Business Ethics, Vol. 43 No. 1, pp. 3-19.

Lee, J., et.al. 2011. The different effects of online consumer reviews on consumers' purchase intentions depending on trust in online shopping malls: an advertising perspective. Internet Research, Vol. 21 No. 2, pp. 187-206. 
Lee, K.H. 2009. Why and how to adopt green management into business organizations?: The case study of Korean SMEs in manufacturing industry. Management Decision, Vol. 47 No. 7, pp. 1101-1121.

Lu, Y., et.al. 2010. From virtual community members to C2C e-commerce buyers: Trust in virtual communities and its effect on consumers' purchase intention. Electronic Commerce Research and Applications, Vol. 9 No. 4, pp. 346-360.

Mishra, D.P, et.al. 1998. Information asymmetry and levels of agency relationships. Journal of Marketing Research, Vol. 35 No. 3, pp. 277-95.

Netemeyer, R.G. et.al. 2005. Conflicts in the work-family interface: links to job stress, customer service employee performance, and customer purchase intent. Journal of Marketing, Vol. 69 No. 2, pp. 130-43.

Pavlou, P.A. 2003. Consumer acceptance of electronic commerce: integrating trust and riskwith the technology acceptance model. International Journal of Electronic Commerce, Vol. 7 No. 3, pp. 101-134.

Schlosser, A.E, et.al. 2006. Converting web site visitors into buyers:how web site investment increases consumer trusting beliefs and online purchase intentions. Journal of Marketing, Vol. 70 No. 2, pp. 133-48.

Sirdeshmukh, D, et.al. 2002. Consumer trust, value, and loyalty in relationalexchanges. Journal of Marketing, Vol. 66 No. 1, pp. 15-37.

Steenkamp, J.B.E.M. \& I. Geyskens. (2006). How country characteristics affect the perceived value of websites. Journal of Marketing, Vol. 70 No. 3, pp. 136150.

Sweeney, J.C. \& G.N. Soutar. 2001. Consumer perceived value: the development of a multipleitem scale. Journal of Retailing, Vol. 77 No. 2, pp. 203-220.

Zhuang, W, et.al. 2010. The impact of perceived value on behavior intention: an empirical study. Journal of Global Business Management, Vol. 6 No. 2, pp. $1-7$. 